\title{
Virus transmission by ultrasonic scaler and its prevention by antiviral agent
}

Prof. Aleš Fidler, DMD, PhDa,b

a University of Ljubljana, Faculty of Medicine, Department of endodontic and restorative dentistry

b University Clinical Centre Ljubljana, Department of endodontic and restorative dentistry

Andrej Steyer, $\mathrm{PhD}^{\mathrm{c}}$

c University of Ljubljana, Faculty of Medicine, Institute of Microbiology and Immunology

Prof. Rok Gašperšič, DMD, PhD ${ }^{\mathrm{d}, \mathrm{e}}$

d University of Ljubljana, Faculty of Medicine, Department of Oral Medicine and Periodontology

e University Clinical Centre Ljubljana, Department of oral medicine and periodontology

\section{Corresponding author:}

Aleš Fidler, DMD, PhD

University Clinical Centre Ljubljana,

Department of endodontic and restorative dentistry

Hrvatski trg 6

SI-1000 Ljubljana,

Slovenia

Phone: +38615224383

ales.fidler@mf.uni-lj.si

abstract word count: 286 , total word count: 3186 , total number of tables: 1 , figures: 3 , number of references: 36

Keywords; Infection Control, Dental; Virology; Aerosols; Sodium Hypochlorite; Dental Scaling, 


\section{ABSTRACT}

During an ultrasonic scaler (USS) operation, droplets and aerosol are generated that may contribute to the transmission of viruses contained in saliva and gingival crevicular fluid. The purpose of this research was to develop an experimental model for testing the spread of viruses during USS instrumentation and to examining the prevention of spreading by replacing the coolant with an antiviral agent. In a virus transmission tunnel, USS operation with saline coolant and delivery of a viral suspension to the vicinity of USS tip generated droplets and aerosol containing Equine Arteritis Virus (EAV). Evaluation of droplet transmission was evaluated with adherent 48h cell culture monolayer RK13 cell lines in standard 48-well-plates positioned at a distance from 30 to $55 \mathrm{~cm}$. The aerosol was collected by a cyclone aero-sampler flow of $100 \mathrm{l} / \mathrm{min}$. Antiviral activity of $0.25 \%$ sodium hypochlorite or electrolyzed water (EOW) was tested by suspension test. The two tested antiviral agents' transmission prevention ability was evaluated by repeating the same experiment as with saline coolant. All experiments were repeated twice. With saline coolant, the cytopathic effect on cells was found in cells up to the distance of $45 \mathrm{~cm}$, with the number of infected wells decreasing with distance. Viral particles were detected in only one AS in a very low concentration $(\leq 4.2 \mathrm{TCID} 50 / \mathrm{ml})$. In suspension test of $0.25 \% \mathrm{NaOCl}$ and EOW, the TCID50/ml was below detection limit after $5 \mathrm{~s}$. With both antiviral agents, no cytopathic effect was found. However, the cytotoxic effect of $0.25 \% \mathrm{NaOCl}$ was evident up to the distance of $35 \mathrm{~cm}$. By USS activity, EAV could be transmitted by droplets up to a distance of $45 \mathrm{~cm}$. Both antiviral agents could prevent virus droplet transmission. The transmission of EAV by aerosol yielded inconclusive results. 


\section{Introduction}

It is well recognized that dental procedures represent a potential way of infection transmission due to extensive generation of droplets and aerosol by using powerdriven instruments, such as ultrasonic scaler (USS), high-speed rotary instruments, and air-and-water syringe. In the past, the spread of bacteria associated with dental procedures has already been extensively studied in real or artificial working environment settings, reporting on large contamination to operator's face and head, patient chest and also surfaces up to 3 meters from the patient mouth (Innes et al. 2021). To reduce bacterial load, preprocedural mouth-rinse was suggested despite the moderate level of evidence to support such action (Marui et al. 2019). The bacterial content of aerosols was reduced 2 to 7 fold by using povidone-iodine and chlorhexidine gluconate as an ultrasonic liquid compared with distilled water in an invivo study (Jawade et al. 2016).

With the COVID-19 pandemic, the focus of dental procedure associated transmission has rapidly changed from bacteria to viruses. Although the SARS-CoV issue in 2004 was recognized in dental literature (Li et al. 2004a; Li et al. 2004b), no research is presently available on virus transmissions associated with dental procedures (Koletsi et al. 2020). It is generally acknowledged that dental procedures represent a high risk of SARS CoV-2 virus transmission(Ather et al. 2020; Meng et al. 2020; Sabino-Silva et al. 2020; Izzetti et al. 2020) due to its presence in saliva (To et al. 2020), gingival crevicular fluid (Gupta et al. 2020), nasopharyngeal, oropharyngeal and bronchial excretions (Liu et al. 2020). For the provision of safe dental care for dental team members and patients, numerous preventive measures were proposed and included in professional (Ather et al. 2020; Meng et al. 2020; Sabino-Silva et al. 2020; Izzetti et al. 2020) and national (Clarkson et al. 2020) COVID-19 prevention guidelines. The measures range from pre-procedure mouth-rinse, use of personal protective equipment, high volume evacuation, air purification (ventilation, filtering, air disinfection), and surface disinfection. Personal protective equipment can protect the dental care providers; however, the contamination of clinical environments by sprays still necessitates periods of "fallow time" between appointments to protect patients and staff (Sergis et al. 2020). A special concern was raised for open plan clinic environments, reporting a safe distance of $5 \mathrm{~m}$ (Holliday et al. 2021) Although preprocedural mouth-rinse is included in most recommendations (Clarkson et al. 
2020), its effectiveness is questionable as no scientific clinical evidence exists for reducing the viral load (Carrouel et al. 2020). So far, antiseptic mouth rinses containing cetylpyridinium chloride or povidone-iodine have shown the highest potential to reduce viral load in infected subjects (Herrera et al. 2020). Thus, there is a high need for effective prevention measures against virus transmission in dentistry. The splatter and aerosol source is a mixture composed of virus-containing body fluids and water from the dental unit water system.

Although a simple replacement of cooling liquid with virucidal agent might have a potential to reduce viral spread, this possibility has not been evaluated. Such an approach would require a highly effective agent capable of virus inactivation in a very short time. Several regents were already found to be effective against coronaviruses in as short as 30 s of suspension test (Kampf et al. 2020). Some of them, like hydrogen peroxide (Boyd 1989) or sodium hypochlorite (Rich and Slots 2015) have already been evaluated for safe use as an oral rinse. Additionally, the electrolyzed water was proposed as an effective and safe biocidal agent for nasal (Yu et al. 2011) or ocular (Sipahi et al. 2019) application.

The aim of the study was twofold, (i) to develop an experimental model for evaluation of viral transmission by USS activity, and (ii) to evaluate reduction of viral transmission with USS by the replacement of water with a virucidal agent. 


\section{Methods}

To evaluate our hypothesis, we have designed a virus transmission tunnel (VTT), thus simulating dental procedure in controlled laboratory conditions. It featured the operating USS in the presence of virus suspension and virus sampling device for a spill, droplets, and aerosol. It consisted of a clear acrylic box, resembling a similar device (Singanayagam et al. 2020), with dimensions of $120 \times 50 \times 40(\mathrm{~L} \times \mathrm{W} \times \mathrm{H})$ manufactured specifically for this purpose (Acrytech, Ljubljana, Slovenia).

At one end of the VTT, a platform for droplet and aerosol generation was positioned $25 \mathrm{~cm}$ above the floor. The piezoelectric USS (Varios 970, NSK dental, Nakanishi Inc. Shimohinata, Japan) with the handpiece (VA2-LUX-HP) and a general prophylactic tip (G4) was firmly positioned in a mechanical holder. For all experiments, the USS was set to General mode, power level to 10 and the coolant level to 3, and flow rate of $17.5 \mathrm{ml} / \mathrm{min}$. The USS tip was positioned into a semi-cylindrical groove, measuring $30 \times 3 \times 3 \mathrm{~mm}(\mathrm{LxW} \times \mathrm{D})$ (Fig 1). In the same groove, a virus suspension was delivered by an IV administration set (Normal set, Ferrari L., Verona, Italy)with a flow rate of $104 \mathrm{ml} / \mathrm{h}(1,73 \mathrm{ml} / \mathrm{min})$ through a pre-curved, $20 \mathrm{G}$ blunt, rounded tip needle ( 0.9X 42mm) (Transcodent, Kiel, Germany), stably mounted with a connecting element (Fig. 1).

\section{Virus suspension and sampling}

For experiments, a laboratory Equine Arteritis Virus (EAV) strain was used. EAV was propagated in a $48 \mathrm{~h}$ cell culture monolayer. A specific cytopathic effect (CPE) with cell rounding and degeneration of cell monolayer is observed in $48 \mathrm{~h}$ post-inoculation in $75 \mathrm{~cm}^{2}$ cell culture flasks. After CPE reaches $90 \%$ of the monolayer, the cell culture flask was freeze-thawed two times, and finally, the whole-cell debris and media were transferred to $50 \mathrm{ml}$ centrifugation tubes. Cell debris was removed by centrifugation $15 \mathrm{~min}$ at $1500 \times \mathrm{g}$. Clear virus suspension was stored at $-80^{\circ} \mathrm{C}$ in $1 \mathrm{ml}$ cryotubes.

One $\mathrm{ml}$ of clear virus suspension with a concentration of $1.33 \times 10^{6} \mathrm{TCID} 50 / \mathrm{ml}$ (infective virus units: $50 \%$ Tissue Culture Infectious Dose per milliliter) was inoculated into 250 $\mathrm{ml}$ sterile saline solution $(0,9 \% \mathrm{NaCl})$, which was delivered to the position of USS tip through infusion system. Virus transmission in the VTT was achieved by simultaneous activation of USS and flow of virus suspension in a duration of $10 \mathrm{~min}$.

Virus sampling 
Virus sampling was performed at three sites: liquid sample (LS), droplet sample (DS), and aerosol sample (AS). At the end of the procedure, the LS was acquired from a mixture of virus suspension and cooling liquid, flowing freely from the groove and collected in a glass jar placed directly under the platform. The DSs were acquired during the procedure by the three 48-well standard cell culture plates $(8.5 \times 12.8 \mathrm{~cm})$ (Cell Culture Multiwell Plate, Cellstar) with adherent 48h cell culture monolayer that were positioned consecutively from the distance of $30 \mathrm{~cm}$ to $55 \mathrm{~cm}$. In total, 108 wells, arranged in 18 lines, with six wells per line, were used as DS. After the procedure, plates were covered, removed, and incubated. The AS was performed using a cyclone air sampler (Coriolis Micro, Bertin Technologies, France), with airflow set at $100 \mathrm{l} / \mathrm{min}$ (Fig 1X). The air inlet was positioned at a distance of $60 \mathrm{~cm}$ from the USS tip and height of $25 \mathrm{~cm}$. The experiment was repeated twice.

\section{Virus transmission evaluation}

The virus was efficiently propagated in an adherent RK13 cell line (source: Oryctolagus cuniculus, kidney, epithelial). Eagle's Minimum Essential Medium (SigmaAldrich, MO) was used for cell culture medium, supplemented with final $10 \%$ fetal bovine serum (EuroClone, Italy) concentration.

Virus concentration in LS and AS was determined with titration on cell monolayer in 96-well microtiter plate. Each 10-fold dilution was inoculated in 8 replicates, including negative control. Briefly, cell culture media was removed from the cell monolayer, and $100 \mu \mathrm{l}$ of virus suspension (LS or AS sample) was added to each well. The inoculated microtiter plate was incubated for up to 4 days in $37^{\circ} \mathrm{C}, 5 \% \mathrm{CO}_{2}$ atmosphere, and $95 \%$ humidity. After four days, cells were screened for CPE, and the number of infected wells was recorded.

Virus transmission in DS was evaluated by CPE formation in exposed microliter plates incubated for up to 4 days in $37^{\circ} \mathrm{C}, 5 \% \mathrm{CO}_{2}$ atmosphere, and $95 \%$ humidity. After four days, cells were screened for CPE, and the number of inoculated wells in each row was recorded.

\section{Irrigant suspension evaluation}

The virucidal ability of two irrigants was evaluated with a suspension test. A $0.25 \%$ $\mathrm{NaOCl}$ and EOW (Table 1) were used. The $\mathrm{pH}$, redox potential (Multi 3630 IDS, WTW, Weilheim, Germany), and free chlorine (Pocket Colorimeter II, Loveland, Colorado, 
USA) were measured and recorded (Table 1). Virus suspension was exposed to the agent, and a reduction of infective virus particles was evaluated after a contact time of 5s, 30s, $1 \mathrm{~min}, 5 \mathrm{~min}$, and $10 \mathrm{~min}$.

\section{Virus transmission prevention evaluation}

The virus transmission prevention test was evaluated with the same experimental setup as for the virus transmission test, except that sterile saline as a cooling agent was replaced with agents evaluated in suspension tests: $0.25 \% \mathrm{NaOCl}$ in the first and EOW in the second experiment. The irrigant flow rate was the same as in the virus transmission test. For each irrigant, the experiment was repeated twice. 


\section{Results}

\section{Virus transmission test}

The estimated virus concentration in the LS sample, collected in the vicinity of the droplet-generating platform, was $3.25 \mathrm{log}$ TCID50/ml. In DSs collected in wells, CPE associated with viral infection was found in the first 16 of 18 lines of cultivation plates. More than one infected well per line was found only in the first seven lines (Fig. 2A). In one of two AS, viral particles were detected in a very low concentration, which was $\leq 0.63 \log \mathrm{TCID}_{50} / \mathrm{ml}$.

\section{Suspension test}

The suspension test showed a highly efficient reduction of virus concentration in a short time (Fig 3). In 5 second contact time, both the EOW and the 0,25\% $\mathrm{NaOCI}$ decreased the $\log \mathrm{TCID} 50 / \mathrm{ml}$ concentration from $6.45 \pm 0.60$ to a value of $\leq 2.8$, which was the limit of detection in our test due to virus dilution. The $\log _{10}$ (conc)/TCID $50 / \mathrm{ml}$ value remained unchanged after more extended periods of observation. The suspension test with saline did not affect the virus concentrations (Fig 3).

\section{Virus transmission prevention test}

In LS, for both irrigation experiments, no infective viral particles were detected. Importantly, a cytotoxic effect of $\mathrm{NaOCI}$ was found in LS for dilutions up to $10^{5}$, while no cytotoxic effect was found for EOW.

In DS, sampled with $0.25 \% \mathrm{NaOCl}$ as an irrigant (Fig 2B), the cytotoxic effect was found in the first five lines, and thus the effect of infective viruses (CPE) could not be evaluated. In lines from 6 to 18, no CPE nor cytotoxic effect was found. With EOW as a coolant (Fig 2C), nor CPE neither cytotoxic effect was found in any line.

In AS, for both irrigation experiments, no infective viral particles were detected. However, for $0.25 \% \mathrm{NaOCl}$ cytotoxic effect was found at $10^{-1}$ dilution. 


\section{DISCUSSION}

The study results indicate that EAV was transmitted mainly by droplets and up to the distance of $45 \mathrm{~cm}$ by USS activity. The transmission of EAV by aerosol, however, yielded inconclusive results. More importantly, the virus droplet transmission could be prevented by a simple saline replacement with a virucidal agent that has already been tested as mouth-rinse for home oral care.

Our aim was to select a non-human viral pathogen, which resembles a similar structure and genome as SARS CoV-2. An Equine Arteritis Virus (EAV) is an animal pathogen, which is species-restricted to Equidae members. EAV is an enveloped virus with a single-stranded, positive-sense RNA genome. EAV is also a member of Baltimore's IV group and presents a similar structure to Coronaviruses, similar stability in the environment, and inactivation by general disinfectant as SARS CoV-2 (Balasuriya et al. 2018; Chan et al. 2020). Besides, EAV is also transmitted through respiratory route and aerosol transmission, although indirect or close contact is required for infection (Balasuriya et al. 2018).

In the first part of the study, we designed an experimental setup to demonstrate the EAV spread by USS action. The EAV predominantly spreads via larger droplets (splatter) that, according to ballistic laws, reach the near surrounding area, as infected droplets consistently infected cells on plates up to the distance of $45 \mathrm{~cm}$ (16 ${ }^{\text {th }}$ well) from the USS tip. These observations are in accordance with a recent review (Sergis et al. 2020) stating that contaminants settle to a great extent on the operator's dominant arm, eyewear, and chest of the patient, and to a lesser extent on the nondominant arm and chest of the operator and assistant. To the best of our knowledge, this is the first proof of the contribution of an USS action to the spread of the virus via droplets to the environment. Although we were able to detect EAV in low concentration in air sample, we failed to achieve the reproducible collection of the infectious virus from the air-sampler. This observation is in accordance with a recent review on air contamination by SARS-CoV-2 in hospital settings (Birgand et al. 2021). Air samples from the close patient environment were positive for SARS-CoV-2 RNA and viable viruses only in $17.4 \%$ and $8.6 \%$, respectively. As the volume of a typical aerosol particle with a diameter of $1 \mu \mathrm{m}$ is $5.23 \times 10^{-13} \mathrm{ml}$, and $3.58 \times 10^{11}$ of such particles may be generated from $1 \mathrm{ml}$, it is possible to calculate by dividing the number of virus particles in $1 \mathrm{ml}$ by the number of aerosol particles, obtained from $1 \mathrm{ml}$ suspension of 
our study. i.e. $1.78 \times 10^{3} / 3,58 \times 10^{11}=4.97 \times 10^{-9}$, representing a fraction of particles actually harboring a virus. This might be the explanation for low percentage of aerosol virus transmission. Another reason could be the virion damage during the sampling process (Pan et al. 2019).

In our experiments, the clear virus suspension with a concentration of log $4.12 \pm 0.60 \mathrm{TCID} 50 / \mathrm{ml}$ and flow of $1.73 \mathrm{ml} / \mathrm{min}$ was diluted with irrigant with flow between 12.5 and $17.5 \mathrm{ml} / \mathrm{min}$. The concentration of $\log 3.25 \pm 0.59 \mathrm{TCID} 50 / \mathrm{ml}$ was measured in LS. This observation is in accordance with a recent paper, stating that mixing the introduced coolant with real saliva also requires consideration (Sergis et al. 2020). In our case, with virus titration control in saline suspension and splatter collected directly at the USS, the concentration reduction was $0.87 \mathrm{log}$, which is near $10 \mathrm{x}$ dilution and goes perfectly with the ratio of virus suspension and irrigant flow. This observation confirms the importance of dilution, stated in previous studies (Epstein et al. 2020; Holliday et al. 2021)

In the second part of the experiment, we managed to prevent the droplet spread of the virus to the surroundings by changing the saline coolant with EOW or hypochlorite. Despite the promising results of our preliminary tests, in which $0.25 \%$ hypochlorite did not show considerable cytotoxicity, such effect was always found in the wells reached by a higher number of droplets (the first six lines). Nevertheless, no cytotoxic effect was found in the wells at a larger distance from the USS tip. It should be noted that in the experiment with the saline, cell infection was apparent to the much greater distance (up to the $16^{\text {th }}$ well). Therefore, the absence of CPE in wells 6-16 can be attributed to the effective inactivation of the virus by $0.25 \%$ hypochlorite.

However, the effective infection prevention of cells was particularly interesting for the EOW experiment, as, despite the absence of cytotoxicity, we never found a single well with CPE suggestive of viral infection. Since all experiments were well controlled and performed sequentially, it is unlikely that the absence of signs of viral infection in these experiments resulted from a methodological error. We may consider our experiments as the first that have clearly shown the possibility of disinfecting the virus in droplets generated by USS by replacing inert coolant with antiseptic irrigant. In addition, EOW showed a high virucidal effect in the suspension test. A low level of cytotoxicity and the high virucidal effect are optimal for highly effective potential disinfectants in dental procedures. Considering the fact that $\mathrm{AS}$ from the $\mathrm{NaOCl}$ experiment exhibited cytotoxic effect already at $10^{-1}$ dilution, we could assume that 
$\mathrm{NaOCl}$-containing aerosol was successfully collected during the experiment. This result could be attributed to the high throughput air sampler used in our case, as in 10 minutes, the whole volume of the VTT was filtered 4-times. Nonetheless, the detection of infective virus particles was not successful in the first part of the experiment.

Besides direct infection by droplets, the proposed approach might also effectively prevent indirect transmission by contaminated surfaces or reduce viral load. It has been demonstrated that SARS CoV-2 might be transmitted indirectly via contaminated surfaces as the virus can survive on surfaces like metal, glass, or plastic for up to a couple of days (Otter et al. 2016; Kampf et al. 2020).

To the best of our knowledge, this is the first dental procedure virus transmission study, performed with viable virus evaluation. The proposed setup also allows evaluating other powered dental devices, such as air turbines, high-speed contra-angles, and dental lasers. As EAV is incapable of infecting humans, the experiments can be safely performed using standard PPE with no risk for the researchers. However, the combination of EAV and RK13 cell line, representing kidney epithelial cells, does not precisely reflect clinical conditions, featuring SARS CoV-2 and respiratory epithelial cells. The use of SARS CoV-2 would require facilities with Biosafety Level 3 conditions, and with inducing aerosols, the whole experiment procedure would not be possible.

EOW was found to have no systemic effects when it was provided as by drinking water to mice during two weeks experiment, which served to the authors as indirect proof for safe usage as a mouthwash (Morita et al. 2011). EOW was already proposed as an effective and safe biocidal agent for nasal (Yu et al. 2011) or ocular (Sipahi et al. 2019) application. Similarly, the 0.25\% sodium hypochlorite has been proposed for oral rinse (Galván et al. 2014; Gonzalez et al. 2015).

It should be noted that our experiments were performed without any splatter or aerosol reduction device in order to maximize the contamination and to test the effect of coolant in the most challenging situation. Using a high vacuum evacuator or similar device, as they are usually used in a clinical setting, would considerably reduce the spread of splatter and aerosol (King et al. 1997; Holloman et al. 2015). Similar to a recent study on atomization from rotary dental instruments (Sergis et al. 2020), the generalization of our findings into the wide variety of clinical settings is difficult due to variability of USS devices and their operating parameters, including power setting tip 
selection and irrigant flow rate. Even larger differences may be found between dental procedures (Allison et al. 2021).

In conclusion, by using the proposed experimental model, we managed to predictably demonstrate virus spread by droplets due to USS action in virus suspension. More importantly, we managed to mitigate the virus spread by a simple substitution of the irrigant with already clinically used virucidal agents, namely sodium hypochlorite and EOW. Future research using the proposed experimental model should include other aerosol and droplet generating dental procedures, additional agents, and ultimately the SARS-Cov-19 virus before clinical application. Nevertheless, the proposed principles for virus spread mitigation seems promising and warrant further evaluation. 


\section{Acknowledgments}

Laboratory Equine Arteritis Virus (EAV) strain was kindly provided by the Institute of Microbiology and Parasitology, Veterinary Faculty, University of Ljubljana, Slovenia.

The work was supported by the Ministry of Higher Education, Science, and

Technology, Republic of Slovenia, under grant number P3-0293 and P3-0083. 


\section{REFERENCES}

Allison JR, Currie CC, Edwards DC, Bowes C, Coulter J, Pickering K, Kozhevnikova E, Durham J, Nile CJ, Jakubovics N, et al. 2021. Evaluating aerosol and splatter following dental procedures: Addressing new challenges for oral health care and rehabilitation. J Oral Rehabil. 48(1):61-72. doi:10.1111/joor.13098.

Ather A, Patel B, Ruparel NB, Diogenes A, Hargreaves KM. 2020. Coronavirus Disease 19 (COVID-19): Implications for Clinical Dental Care. J Endod. 46(5):2020. doi:10.1016/j.joen.2020.03.008.

Balasuriya UBR, Carossino M, Timoney PJ. 2018. Equine viral arteritis: A respiratory and reproductive disease of significant economic importance to the equine industry. Equine Vet Educ. 30(9):497-512. doi:10.1111/eve.12672.

Birgand G, Peiffer-smadja N, Fournier S, Kerneis S, Lescure F, Lucet J. 2021. Assessment of Air Contamination by SARS-CoV-2 in Hospital Settings. 3(12):1-14. doi:10.1001/jamanetworkopen.2020.33232.

Boyd RL. 1989. Effects on gingivitis of daily rinsing with $1.5 \% \mathrm{H} 202$. J Clin Periodontol. 16(9):557-562. doi:10.1111/j.1600-051X.1989.tb02137.x.

Carrouel F, Gonçalves LS, Conte MP, Campus G, Fisher J, Fraticelli L, GadeaDeschamps E, Ottolenghi L, Bourgeois D. 2020. Antiviral Activity of Reagents in Mouth Rinses against SARS-CoV-2. J Dent Res. doi:10.1177/0022034520967933.

Chan KH, Sridhar S, Zhang RR, Chu H, Fung AYF, Chan G, Chan JFW, To KKW, Hung IFN, Cheng VCC, et al. 2020. Factors affecting stability and infectivity of SARS-CoV-2. J Hosp Infect. 106(2):226-231. doi:10.1016/j.jhin.2020.07.009.

Clarkson J, Ramsay C, Aceves-Martins M, Brazzelli M, Colloc T, Dave M, Glenny AM, Goulao B, Lamont T, Richards D, et al. 2020. Recommendations for the reopening of dental services: a rapid review of international sources (substantial update 16 May 2020). Cochrane Database Syst Rev.(May).

Epstein JB, Chow K, Mathias R. 2020. Dental procedure aerosols and COVID-19. Lancet Infect Dis. 3099(Cdc):30636. doi:10.1016/S1473-3099(20)30636-8.

Galván M, Gonzalez S, Cohen CL, Alonaizan FA, Chen CTL, Rich SK, Slots J. 2014. Periodontal effects of $0.25 \%$ sodium hypochlorite twice-weekly oral rinse. A pilot study. J Periodontal Res. 49(6):696-702. doi:10.1111/jre.12151.

Gonzalez S, Cohen CL, Galván M, Alonaizan FA, Rich SK, Slots J. 2015. Gingival bleeding on probing: Relationship to change in periodontal pocket depth and effect of sodium hypochlorite oral rinse. J Periodontal Res. doi:10.1111/jre.12219.

Gupta S, Mohindra R, Chauhan PK, Singla V, Goyal K, Sahni V, Gaur R, Verma DK, Ghosh A, Soni RK, et al. 2020. SARS-CoV-2 Detection in Gingival Crevicular Fluid. J Dent Res. doi:10.1177/0022034520970536.

Herrera D, Serrano J, Roldán S, Sanz M. 2020. Is the oral cavity relevant in SARSCoV-2 pandemic? Clin Oral Investig. 24(8):2925-2930. doi:10.1007/s00784-02003413-2.

Holliday R, Allison JR, Currie CC, Edwards DC, Bowes C, Pickering K, Reay S, 
Durham J, Lumb J, Rostami N, et al. 2021. Evaluating contaminated dental aerosol and splatter in an open plan clinic environment: Implications for the COVID-19 pandemic. J Dent. 105. doi:10.1016/j.jdent.2020.103565.

Holloman JL, Mauriello SM, Pimenta L, Arnold RR. 2015. Comparison of suction device with saliva ejector for aerosol and spatter reduction during ultrasonic scaling. J Am Dent Assoc. 146(1):27-33. doi:10.1016/j.adaj.2014.10.001.

Innes N, Johnson IG, Al-Yaseen W, Harris R, Jones R, KC S, McGregor S, Robertson M, Wade WG, Gallagher JE. 2021. A systematic review of droplet and aerosol generation in dentistry. J Dent. 105:103556.

doi:10.1016/j.jdent.2020.103556.

Izzetti R, Nisi M, Gabriele M, Graziani F. 2020. COVID-19 Transmission in Dental Practice: Brief Review of Preventive Measures in Italy. J Dent Res.:002203452092058. doi:10.1177/0022034520920580.

Jawade R, Bhandari V, Ugale G, Taru S, Khaparde S, Kulkarni A, Ardale M, Marde S. 2016. Comparative evaluation of two different ultrasonic liquid coolants on dental aerosols. J Clin Diagnostic Res. 10(7):ZC53-ZC57.

doi:10.7860/JCDR/2016/20017.8173.

Kampf G, Todt D, Pfaender S, Steinmann E. 2020. Persistence of coronaviruses on inanimate surfaces and their inactivation with biocidal agents. J Hosp Infect. 104(3):246-251. doi:10.1016/j.jhin.2020.01.022.

King TB, Muzzin KB, Berry CW, Anders LM. 1997. The Effectiveness of an Aerosol Reduction Device for Ultrasonic Sealers. J Periodontol. 68(1):45-49. doi:10.1902/jop.1997.68.1.45.

Koletsi D, Belibasakis GN, Eliades T. 2020. Interventions to Reduce Aerosolized Microbes in Dental Practice: A Systematic Review with Network Meta-analysis of Randomized Controlled Trials. J Dent Res. 99(11):1228-1238. doi:10.1177/0022034520943574.

Li RWK, Leung KWC, Sun FCS, Samaranayake LP. 2004a. Severe Acute Respiratory Syndrome (SARS) and the GDP. Part II: Implications for GDPs. Br Dent J. 197(3):130-134. doi:10.1038/sj.bdj.4811522.

Li RWK, Leung KWC, Sun FCS, Samaranayake LP. 2004b. Severe Acute Respiratory Syndrome (SARS) and the GDP. Part I: Epidemiology, virology, pathology and general health issues. Br Dent J. 197(2):77-80. doi:10.1038/sj.bdj.4811469.

Liu R, Yi S, Zhang J, Lv Z, Zhu C, Zhang Y. 2020. Viral Load Dynamics in Sputum and Nasopharyngeal Swab in Patients with COVID-19. J Dent Res. 99(11):1239_ 1244. doi:10.1177/0022034520946251.

Marui VC, Souto MLS, Rovai ES, Romito GA, Chambrone L, Pannuti CM. 2019. Efficacy of preprocedural mouthrinses in the reduction of microorganisms in aerosol: A systematic review. J Am Dent Assoc. 150(12):1015-1026.e1. doi:10.1016/j.adaj.2019.06.024.

Meng L, Hua F, Bian Z. 2020. Coronavirus Disease 2019 (COVID-19): Emerging and Future Challenges for Dental and Oral Medicine. J Dent Res. 2019(5):481-487. 
doi:10.1177/0022034520914246.

Morita C, Nishida T, Ito K. 2011. Biological toxicity of acid electrolyzed functional water: Effect of oral administration on mouse digestive tract and changes in body weight. Arch Oral Biol. 56(4):359-366. doi:10.1016/j.archoralbio.2010.10.016.

Otter JA, Donskey C, Yezli S, Douthwaite S, Goldenberg SD, Weber DJ. 2016. Transmission of SARS and MERS coronaviruses and influenza virus in healthcare settings: The possible role of dry surface contamination. J Hosp Infect. 92(3):235250. doi:10.1016/j.jhin.2015.08.027.

Pan M, Lednicky JA, Wu CY. 2019. Collection, particle sizing and detection of airborne viruses. J Appl Microbiol. 127(6):1596-1611. doi:10.1111/jam.14278.

Rich SK, Slots J. 2015. Sodium hypochlorite (dilute chlorine bleach) oral rinse in patient self-care. J West Soc Periodontol Periodontal Abstr.

Sabino-Silva R, Jardim ACG, Siqueira WL. 2020. Coronavirus COVID-19 impacts to dentistry and potential salivary diagnosis. Clin Oral Investig. 24(4):1619-1621. doi:10.1007/s00784-020-03248-x.

Sergis A, Wade WG, Gallagher JE, Morrell AP, Patel S, Dickinson CM, Nizarali N, Whaites E, Johnson J, Addison O, et al. 2020. Mechanisms of Atomization from Rotary Dental Instruments and Its Mitigation. J Dent Res.:1-7. doi:10.1177/0022034520979644.

Singanayagam A, Zhou J, Elderfield RA, Frise R, Ashcroft J, Galiano M, Miah S, Nicolaou L, Barclay WS. 2020. Characterising viable virus from air exhaled by $\mathrm{H} 1 \mathrm{~N} 1$ influenza-infected ferrets reveals the importance of haemagglutinin stability for airborne infectivity. PLoS Pathog. 16(2):1-21. doi:10.1371/journal.ppat.1008362.

Sipahi H, Reis R, Dinc O, Kavaz T, Dimoglo A, Aydın A. 2019. In vitro biocompatibility study approaches to evaluate the safety profile of electrolyzed water for skin and eye. Hum Exp Toxicol. 38(11):1314-1326. doi:10.1177/0960327119862333.

To KKW, Tsang OTY, Yip CCY, Chan KH, Wu TC, Chan JMC, Leung WS, Chik TSH, Choi CYC, Kandamby DH, et al. 2020. Consistent detection of 2019 novel coronavirus in saliva. Clin Infect Dis. 71(15):841-843. doi:10.1093/cid/ciaa149.

Yu MS, Park HW, Kwon HJ, Jang YJ. 2011. The effect of a low concentration of hypochlorous acid on rhinovirus infection of nasal epithelial cells. Am J Rhinol Allergy. 25(1):40-44. doi:10.2500/ajra.2011.25.3545. 


\section{Table 1}

\begin{tabular}{lcc} 
& $\begin{array}{c}0.25 \% \\
\mathrm{NaOCL}\end{array}$ & EOW \\
& 11.2 & 7.34 \\
$\mathrm{pH}$ & 507 & 765 \\
Eh $(\mathrm{mV})$ & 220 & 22 \\
free chlorine $(\mathrm{mg} / \mathrm{L})$ & & \\
\hline
\end{tabular}

Table 1. Chemical characteristics of antiviral coolants, used in suspension test and virus transmission prevention test 


\section{Figure legends}

Figure 1. Experimental set-up for virus transmission evaluation. (A) - The schematic diagram of the virus transmission tunnel (VTT). (B) - Platform with ultrasonic scaler (USS) handpiece holder and groove, (C) - semi-cylindrical groove with USS tip, and blunt needle for virus suspension delivery, (D) Top view on the virus transmission tunnel, showing (1) - USS device, (2)- platform with USS handpiece and groove, (3) - three consecutively positioned 48-well cell culture plates, and (4)- Air Sampler. (E) USS tip, positioned in the groove, during experiment.

Figure 2. Suspension test for the saline, $0.25 \% \mathrm{NaOCl}$, and electrolyzed water.

Figure 3. The cytopathogenic and cytotoxic effect in droplet samples, obtained from three different coolants. (A) saline, (B) $0.25 \% \mathrm{NaOCl}$, and (C) electrolyzed water. In the case of cytotoxic effect, the cytopathogenic could not have been evaluated. 


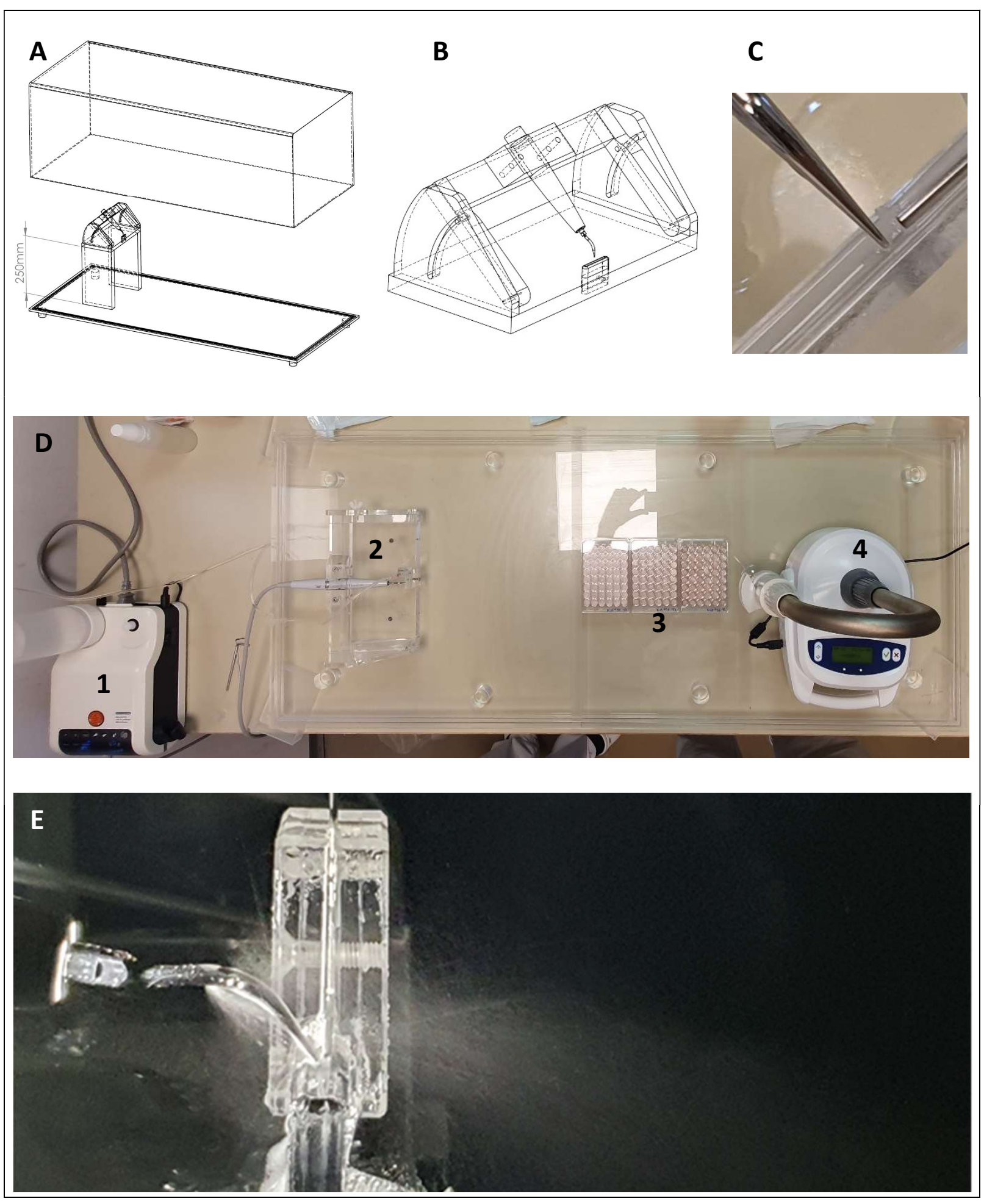




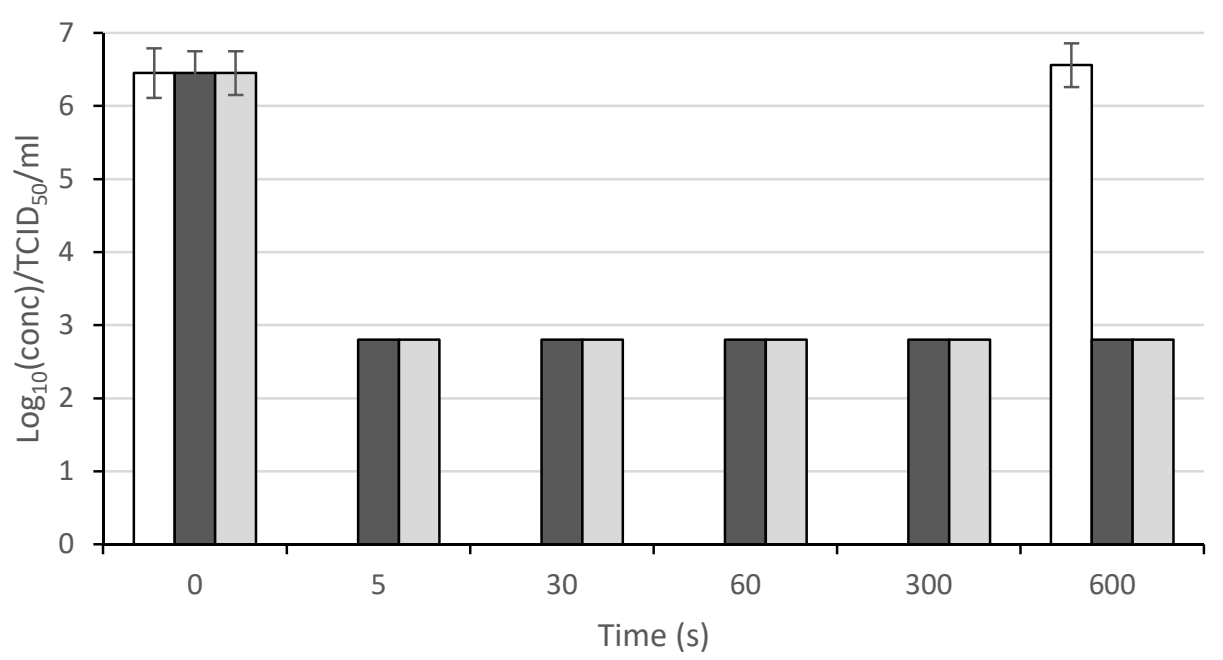

口Saline $\quad \mathrm{NaOCl} 2.5 \% \quad$ 口EOW 

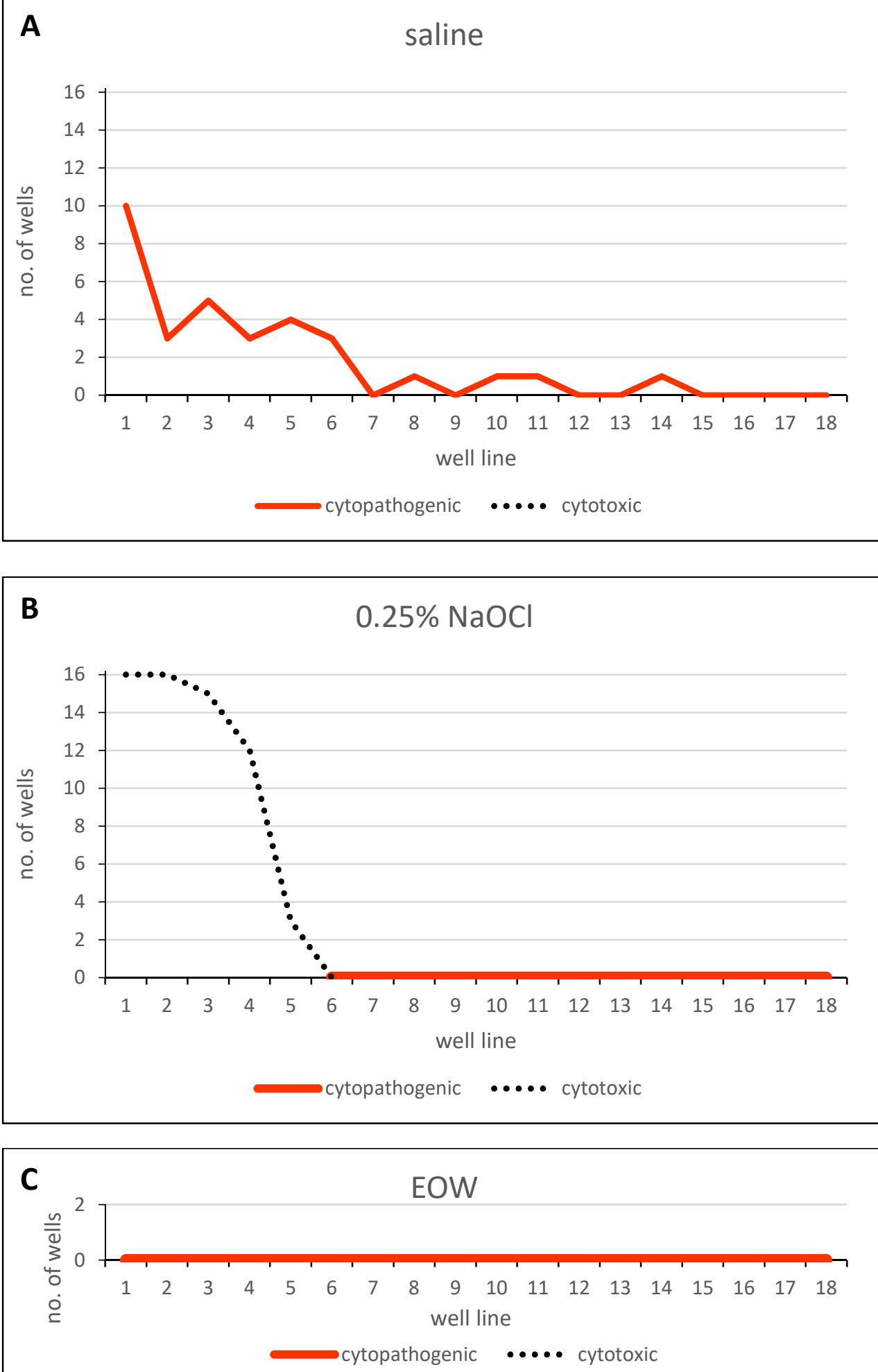